Grzegorz Nieć

Uniwersytet Pedagogiczny im. KEN w Krakowie

Instytut Informacji Naukowej i Bibliotekoznawstwa

\title{
KSIĘGARSTWO W POLSKICH BADANIACH NAD KSIĄŻKĄ DO 1989 ROKU
}

„Historia handlu książką jako temat osobnych studiów i publikacji naukowych pojawiała się o wiele rzadziej, aniżeli historia innych dziedzin życia książki. Trudno dać odpowiedź na pytanie o przyczyny takiego stanu rzeczy (skądinąd utrzymującego się do dziś w wielu krajach)". Tymi słowami Anna Migoniowa rozpoczyna w swojej pracy Historia książki w XVIII wieku rozważania dotyczące "dziejów obiegu i użytkowania książki w piśmiennictwie bibliologicznym" tego stulecia ${ }^{1}$. Konkluzja ta może śmiało posłużyć za punkt wyjścia do przedstawienia księgarstwa w polskich badaniach nad książką do 1989 roku. Jest to zagadnienie, które z pewnością zasługuje na kompleksowe ujęcie bibliograficzne i monograficzne, obejmuje ono bowiem przedział czasowy od momentu narodzin dyscypliny do przełomu ustrojowego w Polsce ${ }^{2}$.

Księgarstwo to ogniwo rozpowszechniania piśmiennictwa polegające na działalności handlowej, której przedmiotem są książki i inne wydawnictwa oraz pokrewne materiały użytku kulturalnego ${ }^{3}$, a także „dział nauki o książce, obejmujący całokształt drogi książki rozprowadzanej sposobami

\footnotetext{
${ }^{1}$ A. Żbikowska-Migoń, Historia ksią̇ki w XVIII wieku. Początki bibliologii, Warszawa 1989, s. 175.

2 Obszerna bibliografia zagadnienia załączona została do popularnego zarysu B. Klukowskiego Księgarstwo i zawód księgarza w Polsce, Warszawa 2008, s. 187-194.

${ }^{3}$ Ksiegarstwo [w:] Encyklopedia wiedzy o ksiązce, red. A. Birkenmajer, B. Kocowski, J. Trzynadlowski, Wrocław 1971, szp. 1311; R. Cybulski, Księgarstwo [w:] Encyklopedia wspótczesnego bibliotekarstwa polskiego, Wrocław 1976, s. 183; tenże, Księgarstwo [w:] Współczesne księgarstwo polskie. Mały słownik encyklopedyczny, red. R. Cybulski, Wrocław 1981, s. 116-123.
} 
handlowymi od momentu wyprodukowania do momentu dostarczenia do odbiorcy"4. W kontekście rozwoju międzynarodowej nauki o książce temat ten był już poruszony przez Krzysztofa Migonia ${ }^{5}$.

Wydzielenie zagadnień księgarskich z całokształtu księgoznawstwa nie jest łatwe, zwłaszcza w odniesieniu do epok wcześniejszych. Zwracał na to uwagę już Jan Muszkowski. W 1936 roku w pierwszym wydaniu swej znanej pracy pt. Życie książki pisał m.in.:

W dawniejszych okresach dziejów książki ścisłe odgraniczenie zagadnień pośrednictwa księgarskiego od spraw produkcji nastręcza bardzo znaczne trudności. Zwłaszcza w warunkach wytwarzania i obiegu książki XV i XVI wieku historia księgarstwa nie daje się oddzielić od historii drukarstwa, działalności wydawniczej, papiernictwa, introligatorstwa. Ale podobny stan trwa po dzień dzisiejszy, szczególnie wszędzie tam, gdzie nakładcy prowadzą sami księgarnie sortymentowe, i to przeważnie najpoważniejsze. Z drugiej strony problematy detalu księgarskiego zazębiają się coraz ściślej z zagadnieniami hurtu, przybierającego w czasach obecnych nowe, nieznane dawniej kształty ${ }^{6}$.

Jednak mimo tych ograniczeń i zapętleń metodologicznych „historia księgarstwa i innych sposobów handlowego rozpowszechniania książki jak twierdzi Krzysztof Migoń - jest dość wyraźnie wyodrębnioną dyscypliną historycznego księgoznawstwa" . Dodajmy, że również problemy współczesnego rynku książki interesują od lat zarówno bibliologów, polonistów, kulturoznawców, jak i z oczywistych względów ekonomistów.

Zagadnienia księgarskie od początku weszły w orbitę zainteresowań polskiej nauki o książce. Z pierwszym historycznym ujęciem księgarstwa mamy do czynienia w pracach Jerzego Samuela Bandtkiego ${ }^{8}$ omawiających dzieje drukarstwa polskiego. Oprócz dawnych drukarzy nakładców, rozprowadzających swoje druki, uwzględnił i osobno potraktował również księgarzy, „którzy nie byli drukarzami”. Joachim Lelewel - jeden z pierwszych

${ }^{4}$ R. Cybulski, Księgarstwo..., s. 122.

${ }^{5}$ K. Migoń, Problematyka księgarska w nauce o książce, „Księgarz” 1972, nr 4, s. 1-8.

${ }^{6}$ J. Muszkowski, Życie ksią̇ki, Warszawa 1936, s. 157.

7 K. Migoń, Nauka o książce. Zarys problematyki, Wrocław 1984, s. 146.

${ }^{8}$ J. S. Bandtkie, Historia drukarń krakowskich od zaprowadzenia druków do tego miasta aż do czasów naszych, wiadomościq o wynalezieniu sztuki drukarskiej poprzedzona, Kraków 1815; Historia drukarń w Królestwie Polskim i Wielkim Księstwie Litewskim, jako i w krajach zagranicznych, w których polskie dzieła wychodziły, t. 1-3, Kraków 1825.

9 Tenże, Historia drukarń krakowskich..., s. 376. 
teoretyków bibliologii w Polsce, inspirowany teoriami Peignota ${ }^{10}$, w swojej koncepcji ujął obok bibliotekarstwa księgarstwo jako element upowszechniania książki.

Bibliopolia czyli księgarstwo, i bibliotekarstwo czyli książnictwo, co jest można mówić najwyższym bibliografii [bibliologii] celem. Wprawdzie księgarstwo od książnictwa jest nieco różne, bo tamto ma na celu wymian i odbyt, handlowe zbycie, to zaś gromadzenie i przechowanie, czasem handlowe nabycie $^{11}$.

Wyodrębnili je również Aleksander Bohatkiewicz i Karol Estreicher ${ }^{12}$. Trzeba jednak zaznaczyć, że owa bibliopolia bywa z reguły tylko napomknięta, zasygnalizowana czy planowana do szerszego potraktowania ${ }^{13}$. Wspomniane dzieła, wykłady poświęcone są przede wszystkim bibliografii, która - że posłużymy się słowami Tadeusza Mikulskiego - „była na początku”14 oraz historii drukarstwa i bibliotekarstwa, nieporównywanie lepiej udokumentowanych obszarów badawczych. Na tym tle imponująco prezentuje się hasło w Encyklopedii powszechnej Orgelbranda z 1864 roku, przygotowane przez Karola Estreichera, i przez wiele lat będące jedynym, tak obszernym zarysem przedmiotowego zagadnienia $\mathrm{w}$ naszym piśmiennictwie ${ }^{15}$. Licząca 45 stron rozprawa ma charakter komparatystyczny, jak byśmy to dzisiaj powiedzieli, ukazuje dzieje „rozpowszechniania utworów literackich za osiągnięciem pieniężnej korzyści” w czasie i przestrzeni na tle historii książki i czytelnictwa. Autor na wstępie wskazuje odmienne kierunki rozwoju księgarstwa w przodujących cywilizacyjnie krajach europejskich i - odnosząc się do Niemiec, gdzie, „najsystematyczniej jest rozklasyfikowane”16 - szkicuje jego model teoretyczny, obejmujący księgarstwo nakładowe, sortymentowe,

${ }^{10}$ B. Koredczuk, Początki teorii bibliologii. „Dictionaire raisonné de bibliologie” (1802-1804) Gabriela Etienne’a Peignota, Wrocław 2005, s. 69, 148-157.

${ }^{11}$ J. Lelewel, Bibliograficznych ksiag dwoje, Wilno 1826 (reprint: Warszawa 1980), s. 254.

12 K. Migoń, Z dziejów nauki o książce, Wrocław 1979, s. 69-72; S. Kubów, Sylwetki polskich bibliologów, Wrocław 1983, s. 55, 69.

${ }_{13}$ M. Kłossowska, Aleksander Wiktor Bohatkiewicz (Pierwszy wileński teoretyk i wykładowca bibliografii), „Studia o Książce”, t. 2, Wrocław 1971, s. 237; M. M. Biernacka, Wykłady Karola Estreichera w Szkole Głównej w Warszawie 1865-1868. Studium bibliologiczne, Warszawa 1989, s. $150-151$.

${ }_{14}$ T. Mikulski, Historia literatury wobec zagadnień ksieggoznawczych [w:] Studia nad książka poświęcona pamięci Kazimierza Piekarskiego, Wrocław 1951, s. 65.

${ }_{15}$ K. Estreicher, Księgarstwo [w:] Encyklopedia powszechna, t. 16, Warszawa 1864, s. 328-373.

16 Tamże, s. 328. 
czyli składowe, antykwarskie i komisowe ${ }^{17}$. Estreicher dość obszernie przywołuje także literaturę przedmiotu, głównie francuską i niemiecką.

Równolegle, wraz z rozwojem nowoczesnego handlu książką, jak i ruchu zawodowego zaczęły pojawiać się podręczniki, poradniki i czasopisma branżowe, coraz bogatsze i różnorodne w treści. W 1894 roku w Warszawie Teodor Paprocki wydał Podręcznik księgarski. Przewodnik praktyczny dla wydawców, księgarzy, pomocników i praktyków księgarskich, niezastąpiony przez następne dziesięciolecia. W czasopismach, oprócz materiałów relacjonujących życie stowarzyszeń, poruszających problemy branży i jej pracowników, zamieszczano artykuły analizujące rynek książki, techniki sprzedaży itp. Pojawiały się także tematy historyczne, które popularyzowały i jednocześnie umacniały tradycję zawodu. Były to nieraz teksty dość rozbudowane, a nawet cykle ciągnące się przez kilka lub kilkanaście numerów ${ }^{18}$. Szczególny rozwój tego rodzaju pism nastąpił w okresie międzywojennym ${ }^{19}$. Ostatnio wydane obszerne studium Moniki Olczak-Kadras, poświęcone ogłoszeniom zamieszczanym w „Przeglądzie Księgarskim”, uświadamia bogactwo zawartego tam materiału źródłowego ${ }^{20}$. W tymże periodyku znajdziemy takie stałe rubryki: Książka $i$ księgarstwo $w$ zwierciadle prasy czy $Z$ praktyki i dla praktyki, a w nich np. oryginalny cykl krótkich, ale niezwykle spostrzegawczych szkiców poświęconych rodzajom klientów ${ }^{21}$.

W XX wieku problematyka księgarska zabierała już znacznie więcej miejsca w coraz częściej ukazujących się pracach księgoznawczych. Nie ma wprawdzie zbyt wielu osobnych opracowań, jednak rozdziały poświęcone temu zagadnieniu w monografiach dotyczących dziejów książki stanowią już poważne pozycje w bibliografii przedmiotu. Autorów, często przecież będących bibliofilami, utrzymujących nieraz ścisłe kontakty z księgarzami i antykwariuszami, nie trzeba było przekonywać do słuszności podejmowania tych tematów. Ich aktywność objawiała się także dużą ilością drobnych publikacji na łamach periodyków środowiskowych czy

\footnotetext{
17 Tamże, s. 328-329.

${ }_{18}$ Np.: H. Łopieński, Księgarstwo polskie na Rusi, „Przegląd Księgarski” 1939, R. 25: nr 2, 4, $6,8,9,12,17 / 18$.

${ }_{19}$ O prasie księgarskiej: S. Tarkowski, Czasopisma księgarskie w Polsce, „Księgarz” 1963, nr 2; R. Salinger, „Przegląd Księgarski” w latach 1918-39, „Księgarz” 1971, nr 3, s. 44-54; B. Klukowski, Księgarstwo i zawód księgarza w Polsce, Warszawa 2008, s. 133-149.

${ }_{20}$ M. Olczak-Kardas, Księgarstwo w II Rzeczypospolitej w świetle ogłoszeń w „Przeglądzie Księgarskim", Kielce 2012.

${ }^{21}$ R.P.K., Klient staty (1938, nr 4, s. 28-29); Klient niepozorny (1938, nr 5, s. 42-43); Klient $z$ fanaberiami (1938, nr 6, s. 51); Klient niezdecydowany (1938, nr 7, s. 59); Klient małoletni (1938, nr 8, s. 69); Klientka (1938, nr 9).
} 
w formie okazjonalnych druków ${ }^{22}$. Przywołać warto przynajmniej kilka znaczących dzieł, z których parę dedykowano uczestnikom zjazdów bibliofilskich. W kolejności chronologicznej są to: Cracovia impresorum $X V$ et XVI saeculorum Jana Ptaśnika, zawierające rozdział Księgarze oraz we wstępie liczne materiały archiwalne, uporządkowane chronologicznie i zindeksowane pod hasłem „Biblipolae”23; Anny Jędrzejowskiej Książka polska we Lwowie w XVI wieku, a w niej rozdział pt. Ksieggarstwo ${ }^{24}$; Marii Wojciechowskiej, $Z$ dziejów książki polskiej w Poznaniu w XVI wieku, którą otwiera obszerny rozdział Księgarstwo poznańskie do roku $1600^{25}$. Niezbyt rozbudowany, ale ważny z uwagi na autora i rangę publikacji, jest fragment traktujący o „pośrednictwie” w rozprawie o książce polskiej XV i XVI wieku Kazimierza Piekarskiego, która znalazła się w pomnikowym wydawnictwie Polskiej Akademii Umiejętności - Kultura Staropolska z 1932 roku $^{26}$. Oprócz wspomnianego dzieła Ptaśnika materiały do dziejów drukarstwa i księgarstwa wydawali m.in. Artur Benis ${ }^{27}$ czy - wspomniana już - Anna Jędrzejowska ${ }^{28}$. W latach trzydziestych z kolei Tadeusz Turkowski podjął się trudu ogłoszenia archiwaliów drukarni i księgarni Józefa Zawadzkiego w Wilnie ${ }^{29}$. Również inicjatywa Związku Księgarzy Polskich - „Biblioteka Księgarska” zapoczątkowana została poważną edycją źródłową. Był to Projekt organizacji księgarstwa polskiego z czasów Królestwa Kongresowego w opracowaniu Tadeusza Sterczyńskiego ${ }^{30}$. Z osobnych opracowań, jakie

${ }_{22}$ Zob. m.in.: M. Czechowski, Czasopisma bibliofilskie (Przewodnik Antykwarski. Wiadomości Antykwarskie „Bibliofila Polskiego”. Wiadomości Bibliofilskie. Bibliofil Polski. Szpargały. Kurier Antykwarski. Kurier Bibliofilski), „Roczniki Biblioteczne” 1986, R. 30: z. 1-2, s. 241-257; T. Ulewicz, Nad „Silva Rerum”. Tradycja i rozeznanie wyjściowe [w:] Silva Rerum. Series nowa..., Kraków 1981, s. 7-15.

${ }^{23}$ Cracovia impresorum XV et XVI saeculorum, edidit Joannes Ptaśnik, Leopoli 1922, s. 85110, 405-407.

${ }^{24}$ A. Jędrzejowska, Książka polska we Lwowie w XVI w., Lwów 1928, s. 55-74. Książka dedykowana uczestnikom III. Zjazdu Bibliofilów we Lwowie.

${ }^{25}$ M. Wojciechowska, Z dziejów książki polskiej w Poznaniu w XVI wieku, Poznań 1929, s. 1-42. Książka dedykowana uczestnikom IV. Zjazdu Bibliofilów w Poznaniu, 30 maja do 2 czerwca 1929 r.

${ }^{26}$ K. Piekarski, Książka w Polsce XV i XVI wieku [w:] Kultura Staropolska, Kraków 1932.

27 A. Benis, Materiały do historii drukarstwa i ksieggarstwa w Polsce, „Archiwum do dziejów literatury i oświaty w Polsce”, t. 8, Kraków 1892.

28 A. Jędrzejowska, Inwentarz księgarni Baltazara Hybnera z r. 1592, Lwów 1929.

${ }_{29}$ Materialy do dziejów literatury i oświaty na Litwie i Rusi. Z archiwum drukarni i księgarni Józefa Zawadzkiego $w$ Wilnie z lat 1805-1865, zebrał T. Turkowski, t. 1-3, Wilno 1935-1937.

${ }^{30}$ Projekt organizacji księgarstwa polskiego z czasów Królestwa Kongresowego, z rękopisu Biblioteki Uniwersyteckiej w Warszawie wydał i przedmową poprzedził T. Sterczyński, „Biblioteka Księgarska" t. 1, Warszawa 1930. 
wyszły przed 1939 rokiem, wymienić wypada książkę Adolfa Pawińskiego o Michale Gröllu ${ }^{31}$, poświęconą jednak głównie jego aktywności wydawniczej; bibliofilski druk Mieczysława Opałka Bibliopole lwowscy $y^{32}$ oraz solidne rozprawy Łukasza Kurdybachy o księgarni Hebanowskiego we Lwowie $^{33}$ i Stefana Rosiaka o wileńskiej księgarni Elizy Orzeszkowej ${ }^{34}$. W tym ostatnim przypadku znakomita część pracy omawia głównie przedsięwzięcia wydawnicze firmy. Wspominane prace cechuje obszerna baza archiwalna, pozyskiwana $\mathrm{z}$ reguły bardzo skrupulatnie. Warto przypomnieć, że Kazimierz Piekarski z rezerwą odnosił się do badaczy opierających swoje wywody przede wszystkim na tego rodzaju materiałach. Wychodził z założenia, że „pierwszorzędnym źródłem do badania drukarstwa jest sama książka”35. „Przeciwstawiam się tu - czytamy dalej - szkole śp. Jana Ptaśnika, z której wyszły trzy wysokiej wartości, jakkolwiek jednostronne prace", wymienione wyżej: samego Ptaśnika (Cracovia impresorum...) oraz Marii Wojciechowskiej i Anny Jędrzejowskiej ${ }^{36}$. Piekarski zwracał uwagę, że w znanych mu źródłach występuje wiele informacji mało istotnych, które często wypaczają obraz dziejów produkcji i rozpowszechniania wydawnictw, zaś „niesięganie do książki samej doprowadza nawet czasami do najdowolniejszej interpretacji tych drugorzędnych i fragmentarycznych wiadomości" ${ }^{37}$. Wprawdzie w zakresie księgarstwa uwagi te mogą być mniej zasadne, to kiedy przyjrzymy się bliżej, możemy i w tym obszarze znaleźć przykłady, gdzie natłok skądinąd ciekawych informacji przysłania zasadnicze problemy, w pamięci zaś pozostaje chociażby to, że „Piotr z Lubeki nie poprzestawał na samym księgarstwie. Sprzedawał również śledzie..." ${ }^{38}$. W zakresie „pośrednictwa zawodowego, jak i prywatnego" książki w dawniejszych okresach Piekarski zalecał przede wszystkim śledzenie „śladów wędrówek, które odbywała w przeszłości”, badając ją samą. Istotną wska-

${ }^{31}$ A. Pawiński, Michał Gröll. Obrazek na tle epoki stanisławowskiej, $z$ dodaniem spisu wydawnictw Grölla, ułożonego przez Zygmunta Wolskiego, Kraków 1896.

${ }^{32}$ M. Opałek, Bibliopole lwowscy, Lwów 1928. Ta bibliofilska gawęda o wydawcach i księgarzach lwowskich, odbita na papierze czerpanym u Artura Goldmana we Lwowie, dedykowana była III Zjazdowi Bibliofilów Polskich we Lwowie (26-29 maja 1928).

${ }^{33}$ Ł. Kurdybacha, Ksiegarnia Ignacego Antoniego Hebanowskiego we Lwowie 1704-1715. Studium z dziejów oświaty i kultury Ziemi Czerwieńskiej, Lwów 1937, „Biblioteka Towarzystwa Miłośników Książki” we Lwowie, nr 19.

${ }^{34}$ S. Rosiak, Księgarnia „E. Orzeszkowa i S-ka” w Wilnie 1879-1882, „Biblioteczka Wileńska” nr 9, Wilno 1938.

${ }_{35}$ K. Piekarski, Książka w Polsce..., s. 354.

36 Tamże.

37 Tamże.

${ }^{38}$ M. Wojciechowska, $Z$ dziejów książki..., s. 5. 
zówką były również oprawy. W tym wypadku zaproponował przekonujący zarys procedury badawczej ${ }^{39}$.

Podsumowując okres do wybuchu II wojny światowej, należy zwrócić uwagę na wzrastającą dynamikę rozwoju badań nad księgarstwem. Obejmowały one szeroki zakres chronologiczny, jak też stawały się coraz bardziej spójne i przejrzyste metodologicznie. Zagadnienia te znalazły swoje miejsce $\mathrm{w}$ rozważaniach teoretycznych, porządkujących i inspirujących badania, nie tylko u wspomnianych Kazimierza Piekarskiego i Jana Muszkowskiego, ale również Mieczysława Rulikowskiego i Stanisława Orsini-Rosenberga ${ }^{40}$. Księgarstwo jest dla nich „nieodłączną częścią zintegrowanego procesu bibliologicznego"41. Muszkowski w Życiu książki zaproponował dość kompleksowe i szerokie ujęcie zagadnień księgarskich, które wciąż pozostaje pożyteczne i inspirujące. Jego systematyka zagadnień, jak to określił, „bibliologiczno-gospodarczych”, przedstawia się następująco: „I Historia księgarstwa; II Stosunek handlu księgarskiego do: 1. Wytwórczości książki, 2. Konsumpcji książki, 3. Innych gałęzi produkcji i handlu, 4. Stanu rynków gospodarczych w kraju i zagranicą; III Technika (praktyka) księgarska; IV Organizacja stanu księgarskiego: 1. Stan prawno-administracyjny, 2. Szkolenie zawodowe, 3. Organizacje zawodowe" ${ }^{\prime 2}$. W zamieszczonym komentarzu najbardziej znamienne i istotne wydaje się być przekonanie, że to właśnie drugi blok tematów „zmierza do wyznaczenie księgarstwu właściwego miejsca w całokształcie poczynań kulturalnych z jednej strony, gospodarczych - z drugiej"43.

Największa uwaga badaczy skupiła się jednak na początkach dziejów polskiej książki drukowanej i tym samym księgarstwa tamtego czasu. Na tym tle opracowania dotyczące wieku XVIII i XIX prezentują się nader skromnie, choć widać pewne ożywienie w tym obszarze badań w latach trzydziestych ubiegłego wieku, zgodnie zresztą $\mathrm{z}$ formułowanymi postulatami ${ }^{44}$. Zrządze-

${ }^{39}$ K. Piekarski, Książka w Polsce..., s. 372-373. O analizie typograficznej Piekarskiego i jej kontynuacjach zob.: T. Mikulski, Historia literatury wobec zagadnień księgoznawstwa [w:] Studia nad ksiązką..., Warszawa 1951, s. 70 i n.; M. Kocójowa, Metoda topograficzna w badaniach nad książką i biblioteka [w:] Studia bibliograficzno-bibliologiczne, red. M. Kocójowa, Kraków 1996, s. $165-174$.

${ }^{40}$ M. Rulikowski, Księgoznawstwo. Przeszłość, stan obecny, nowe kierunki wiedzy o książce, Warszawa 1936, s. 55; S. Orsini-Rosenberg, Socjologia słowa drukowanego, Warszawa 1931, s. 28.

${ }^{41}$ K. Migoń, Problematyka księgarska..., s. 3.

${ }^{42}$ J. Muszkowski, Życie książki... 1936, s. 176.

${ }^{43}$ Tamże, s. 177.

${ }^{44}$ We wstępie do Projektu organizacji księgarstwa... czytamy m.in.: „Mało istnieje dziedzin tak dalece zaniedbanych, jak systematyczne i źródłowe opracowanie dziejów księgarstwa polskiego, zwłaszcza czasów nowszych. Podczas gdy przeszłość drukarstwa naszego przyciągała, po- 
niem losu nie doszło do opracowania i publikacji dziejów wielkiej i znaczącej Firmy Gebethner i Wolff przez Jana Muszkowskiego. Materiały spłonęły w pożarze Warszawy ${ }^{45}$, a pozostało tylko skromne, acz staranne wydawnictwo jubileuszowe z 1938 roku, które daje przedsmak tego, co zamierzał i mógł wykonać autor ${ }^{46}$. Ten widoczny wzrost ilości publikacji w okresie międzywojennym postrzegać należy przede wszystkim w kontekście dynamicznego rozwoju księgoznawstwa polskiego, a także rozwoju organizacyjnego księgarstwa, tożsamości zawodu. Metodologicznie dominują ujęcia typowo historyczne, oparte na archiwaliach, pojawiają się jednak koncepcje nowe, swoiste dla kształtującej się dyscypliny i przedmiotu jej zainteresowania. Teoria coraz częściej łączy się z praktyką, co nie powinno dziwić, szczególnie w przypadku bibliotekarstwa i księgarstwa ${ }^{47}$. Uderzająca i znamienna jednocześnie jest ilość inicjatyw bibliofilskich, publikacji o podwyższonym standardzie edytorskim, dedykowanych kolejnym zjazdom, rocznicom. Ma to związek z żywotnością i charakterem ruchu bibliofilskiego końca XIX wieku i II Rzeczypospolitej, którego trzon stanowili wybitni uczeni i liczni, zasłużeni „pracownicy książki”, łączący pasje kolekcjonerskie z pracą badawczą ${ }^{48}$.

Przywołany wcześniej Jan Muszkowski w pierwszym wydaniu Życia książki pisał o księgarstwie, „przybierającym w czasach obecnych [lata trzydzieste XX wieku] nowe, nieznane dawniej kształty"49. Kształty te, które materializowały się na jego oczach, jak i te istniejące od stuleci, w ciągu kilkunastu lat od wydrukowania cytowanego dzieła praktycznie przestały istnieć w Polsce. Zastąpił je zupełnie nowy porządek, zbudowany na odmiennych zasadach. W drugim wydaniu, jakie przygotowano w $1951 \mathrm{roku}^{50}$, fragmenty dotyczące ruchu wydawniczego i księgarstwa musiały zatem ulec daleko idącym modyfikacjom, zgodnym z wprowadzanymi zasadami. Porównanie obydwu wydań nie jest zresztą przedmiotem tego artykułu. Zwrócę jedynie uwagę na wymowny fakt zmiany tytułu odpowiedniego rozdziału, który w 1936 roku brzmiał: Handel księgarski, a w 1951 - Księgarstwo.

cząwszy od pierwszej połowy XVIII w., wytrawnych badaczy i może się wykazać kilku próbami ujęcia większych całości, księgarstwem, jako oddzielną gałęzią handlową, mało kto się zajmował i zawsze dorywczo" (tamże, s. VII).

${ }^{45}$ J. Muszkowski, Życie książki, wydanie drugie ilustrowane i rozszerzone, Warszawa 1951, s. 234.

${ }^{46}$ Z dziejów firmy Gebethner i Wolff 1857-1937, oprac. J. Muszkowski, Warszawa 1938.

${ }^{47}$ K. Migoń, $Z$ dziejów nauki..., s. 73-99.

48 C., J. Duninowie, Philobiblon polski, Wrocław 1983, s. 148-165.

49 J. Muszkowski, Życie książki... 1936, s. 157.

50 Tamże. 
Odrodzone po wojnie księgarstwo odtwarzało, a na Ziemiach Odzyskanych budowało na nowo swoje struktury handlowe i organizacyjne, oddając przy tym narodowi i państwu nieocenione usługi. Jednak po kilku latach, kiedy komuniści umocnili swoją władzę, przystąpiono do likwidacji prywatnego ruchu wydawniczego i księgarstwa, które od 1950 roku stały się ogniwami scentralizowanej gospodarki i jednocześnie elementami machiny propagandowej. W sposób szczególny było to odczuwalne w okresie stalinizmu i trwało nieprzerwanie - $\mathrm{z}$ różnym nasileniem - do upadku systemu w 1989 roku $^{51}$. W nowej sytuacji inny wymiar i charakter zyskały także badania nad księgarstwem, które rozwijały się w ramach szeroko pojmowanej nauki o książce, a także ekonomii. Ewoluowały one w określonym klimacie politycznym, ideologicznym, falującym jednak w czasie i przestrzeni. Z jednej strony rozwój bibliologii, bibliotekoznawstwa, powstawanie i rozbudowa katedr oraz instytutów na wyższych uczelniach ${ }^{52}$ i utworzenie w 1954 roku przy Bibliotece Narodowej Instytutu Książki i Czytelnictwa ${ }^{53}$, z drugiej zaś scentralizowane i rozbudowane struktury rynku książki, mimo oczywistych ograniczeń, niewątpliwie sprzyjały podejmowanym inicjatywom badawczym i wydawniczym. Dom Książki - monopolista na rynku, jak i utworzone po 1956 roku Stowarzyszenie Księgarzy Polskich inspirowały wiele inicjatyw edukacyjnych, naukowych i popularyzujących wiedzę o księgarstwie. Już w drugim roku działalności, powstał w ramach SKP Klub Miłośników Historii Księgarstwa, skupiający się głównie na działaniach dokumentacyjnych ${ }^{54}$. Niezwykle istotnym elementem całego systemu była prasa fachowa ${ }^{55}$, gdzie ogłaszano teksty, nieraz całkiem obszerne opra-

51 Zob.: S. A. Kondek, Władza i wydawcy. Polityczne uwarunkowania produkcji książek w Polsce w latach 1944-1949, Warszawa 1993; S. A. Kondek, Papierowa rewolucja. Oficjalny obieg ksiqżek $w$ Polsce w latach 1948-1955, Warszawa 1999, s. 16-171.

${ }_{52}$ Zob. m.in.: K. Migoń, Pół wieku Instytutu Informacji naukowej i Bibliotekoznawstwa Uniwersytetu Wrocławskiego (1956-2006) [w:] Dokument, książka, biblioteka w badaniach naukowych i nauczaniu uniwersyteckim, red. M. Skalska-Zlat, A. Żbikowska-Migoń, Wrocław 2008, s. 169-179; B. Świderski, Historia Katedry Bibliotekoznawstwa i Informacji Naukowej UŁ w latach 1945-1987 [w:] Rozwój i perspektywy bibliologii polskiej [materiały konferencji jubileuszowej z okazji 50-lecia Katedry Bibliotekoznawstwa w Uniwersytecie Łódzkim, 4-5 XII 1995], s. 1-9; B. Bieńkowska, Czas próby. Studia bibliotekoznawcze w Uniwersytecie Warszawskim po trzydziestu pięciu latach, „Kronika Warszawy” 1989, t. 2, s. 185-196.

${ }_{53}$ N. Kraśko, Instytut Książki i Czytelnictwa - kształtowanie się struktury i zakresu zainteresowań [w:] Ludzie i książki, red. J. Kostecki, Warszawa 2006, s. 203-232.

${ }^{54}$ F. Trzaska, Klub Miłośników Historii Księgarstwa. Sylwetki członków, Warszawa 2000.

${ }_{55}$ M. Tobera, Od „Przegladu Księgarskiego” do „Biblioteki Analiz”. Uwagi na temat dziejów polskiej prasy branżowej o rynku ksiażki (1910-2010) [w:] 350 lat prasy polskiej, red. M. Jabłonowski [i in.], Warszawa 2012, s. 135-156; I. Janowska-Woźniak, 25 lat „Przeglądu Księgarskiego i Wydawniczego" [w:] 350 lat prasy..., s. 211-219. 
cowania dotyczące dziejów i współczesności ${ }^{56}$. Należy jednak zaznaczyć, że niektóre publikacje mają już dzisiaj charakter wyłącznie źródłowy. Myślę tu przed wszystkim o doniesieniach prasowych, publicystyce, sprawozdawczości itp. Różna jest też wartość i użyteczność wszelkiego rodzaju opracowań okazjonalnych, rocznicowych ${ }^{57}$. Miały one często charakter propagandowy, zideologizowany.

W 1951 roku ukazała się zmodyfikowana wersja Życia książki Muszkowskiego, zaktualizowana w warstwie informacyjnej, ale i wzbogacona rytualnymi sformułowaniami i odwołaniami do klasyków - Engelsa, Lenina, Stalina i Bieruta oraz radzieckiej literatury przedmiotu. Mimo to praca zachowała swoje walory poznawcze i użyteczne, była i wciąż jeszcze pozostaje ważnym kompendium wiedzy księgoznawczej. Transformacja ustrojowa, jaka nastąpiła po 1989 roku, pozbawiła aktualności części dotyczące ruchu wydawniczego i księgarstwa, ale za to przywróciła w sporej mierze taki walor wydaniu pierwszemu.

Równolegle niemal z nową wersją Życia książki Jana Muszkowskiego Związek Księgarstwa Polskiego wydrukował skrypty ${ }^{58}$ na potrzeby organizowanych kursów, m.in.: Okno księgarni ${ }^{59}$ i Księgoznawstwo w zarysie ${ }^{60}$. W tym czasie ukazało się także obszerne Księgarstwo Adama Klimowicza na Wyższej Szkole Ekonomicznej w Łodzi ${ }^{61}$, obejmujące „dość szeroki zakres zagadnień z nauki o książce, oraz o organizacji i ekonomice handlu książką, który można traktować jako wstęp do zawodowego kształcenia pracowników księgarstwa uspołecznionego" ${ }^{62}$. Szczególnie na tym ostatnim skrypcie epoka odcisnęła widoczne piętno.

56 Jeden z obszarów zainteresowania czasopism księgarskich PRL przedstawiłem [w:] G. Nieć, Antykwariaty Przedsiębiorstwa Państwowego „Dom Książki” w latach 1951-1989 w świetle polskiej prasy księgarskiej, „Roczniki Biblioteczne” R. 56 (2012), s. 137-171.

${ }^{57}$ Przykładowo: Sześćset lat w służbie książki 1364-1964, oprac. A. Klimowicz, Warszawa 1964; Ksiegarstwo w 25-leciu wyzwolonej Opolszczyzny, [red. B. Fila], Opole 1970; XX lat P.P. „Dom Ksiązki” w Poznaniu, Poznań 1970. W tej ostatniej na przykład, liczącej 80 stron, charakterystyczny jest już dobór samych zdjęć wystaw księgarskich z okazji: 50-lecia Rewolucji Październikowej, rocznicy Układu Warszawskiego, Festiwalu Kultury Radzieckiej, 25 rocznicy PPR, Konferencji Wojewódzkiej PZPR, V Zjazdu PZP, śmierci Ho Szi Mina, 1 maja, Dni Leninowskich, czy imprez poświęconych książce radzieckiej i enerdowskiej, o Dniach Książki społeczno-politycznej nie wspominając.

${ }^{58}$ Spis wydanych w latach 40., 50. skryptów jest obszerny i obejmuje niespełna czterdzieści tytułów. Zob.: wystawa pod nazwą Książka - księgarstwo - praca księgarska. Katalog, Warszawa 1962, s. 17-19.

59 T. Rojewski, Okno ksiegarni. Budowa i dekoracja, Warszawa 1949.

${ }^{60}$ Ksiegoznawstwo w zarysie, oprac. K. Świerkowski, Warszawa 1950.

${ }^{61}$ A. Klimowicz, Księgarstwo, Warszawa 1953.

${ }^{62}$ Tamże, s. 1. 
Wraz $\mathrm{z}$ rozwojem zawodowego szkolnictwa księgarskiego ${ }^{63}$ pojawiały się wciąż nowe podręczniki i inne fachowe opracowania, m.in.: Obrót księgarski. Organizacja i technika Kazimierza Malawskiego (Warszawa 1960); Organizacja i ekonomika księgarstwa Stanisława Połcia (Warszawa 1962); Ekonomika księgarstwa Stanisława Malawskiego i Stanisława Połcia (cz. 1-2, Warszawa 1968); Reklama i propaganda ksiązki Tadeusza Hussaka (cz. 1-2, Warszawa 1969-1970) czy Ksiegoznawstwo Kazimierza Rzewuskiego (Warszawa 1969, 1987). W sposób szczególny wyróżnić należy dwa podręczniki księgarstwa antykwarycznego Stanisława Tarkowskiego ${ }^{64}$ i Mieczysława Szymańskiego ${ }^{65}$.

Rozwój instytucji i czasopism naukowych z zakresu nauki o książce przyniósł niemałe pokłosie w zakresie badań historycznych i teoretyczno-praktycznych nad księgarstwem oraz dotyczących współczesności. Przyswojono również $\mathrm{w}$ pewnym, ograniczonym $\mathrm{z}$ powodów politycznych, zakresie dorobek zagraniczny ${ }^{66}$. Zdecydowanie większym jednak zainteresowaniem cieszyły się sprawy dziejów książki i bibliotek. Tendencja ta jest widoczna na przykładzie zawartości „Roczników Bibliotecznych” i „Studiów o książ$\mathrm{ce}^{\prime \prime}{ }^{67}$, aczkolwiek i tu ogłoszono sporo znaczących rozpraw w interesującym nas zakresie ${ }^{68}$. Podobnież, z uwagi na wskazane wyżej związki osobo-

${ }^{63}$ T. Hussak, Dorobek kształcenia księgarzy. 60 lat istnienia szkół księgarskich, Warszawa 2010.

${ }^{64}$ S. Tarkowski, Antykwariat księgarski I-XII, „Księgarz” 1957, nr 7-8, 9; 1958, nr 1-2, 3-4, 5, $6,7,9,11,12,16,17-18$ i osobne wydanie nakładem SKP Antykwariat. Zarys wiadomości, „Biblioteka Księgarza”, Warszawa 1960.

${ }^{65}$ M. Szymański, Antykwariat księgarski, Warszawa 1974, „Biblioteka Szkolenia” Zjednoczenia Księgarskiego i wydany następnie w 1989 r. przez SKP w wersji znacznie poszerzonej pt. Świat starych książek (Antykwariat księgarski), Warszawa 1989.

${ }^{66}$ Oprócz przekładów pism Roberta Escarpita i innych socjologów literatury, w mniejszym lub większym stopniu dotyczących księgarstwa, mam tu na myśli jeszcze recenzje, jakie ukazywały się w czasopismach bibliologicznych i bibliotekarskich oraz prasie branżowej, a także prace Krzysztofa Migonia, przede wszystkim Nauka o książce wśród innych nauk społecznych (Wrocław 1976) i Nauka o książce (Wrocław 1980).

${ }^{67}$ Wśród 1088 pozycji bibliografii zawartości za lata 1957-1986 „Roczników Bibliotecznych” tematyka księgarska to zaledwie dwadzieścia kilka pozycji, które pomieszczone są w dziale „Księgarstwo i ruch wydawniczy”. Podobnie niewielką ilość tego rodzaju tematów znajdziemy w „Studiach o Książce”. (M. Rotterowa, „Roczniki Biblioteczne”. Bibliografia zawartości tomów I-XX (1957-1976), Wrocław-Warszawa [1976], s. 23-25; A. Mendykowa, „Roczniki Biblioteczne”. Bibliografia zawartości tomów XXI-XXX (1977-1986), s. 19-20; „Studia o Książce”. Bibliografia zawartości tomów I-X (1970-1980), „Studia o Książce”, 1980, t. 10, s. 12-13).

${ }^{68}$ M.in.: S. Januszek, Dzieje księgarstwa w Kielcach w latach 1826-1939, „Roczniki Biblioteczne" 1968, R. 12, z. 1-4, s. 237- 298; B. Zawierucha, Bestsellery w Polsce w latach 1945-1980. (Próba analizy), „Roczniki Biblioteczne” 1984, R. 28, z. 1-2, s. 211-229; E. Różycki, Z dziejów handlu książka i jej cen we Lwowie w pierwszej ćwierci XVII wieku, „Roczniki Biblioteczne” 1985 R. 29, z. 1-2, s. 185-208 czy kilka tekstów Andrzeja Kłossowskiego o księgarstwie polskim za granicą. 
we i instytucjonalne księgarstwa, a także szerszy, monograficzny charakter niektórych przedsięwzięć badawczych, dzieje księgarstwa odnajdujemy w wielu publikacjach dotyczących historii książki i ruchu wydawniczego, aczkolwiek nie zawsze są one wyeksponowane w takim stopniu, na jaki by zasługiwały. Zdarzały się jednak inicjatywy, w których kładziono szczególny nacisk na to ogniwo rynku książki. Myślę tutaj m.in. o publikacjach: Drukarze, ksieggarze, bibliofile krakowscy 1750-1815 (Kraków 1962) Jana Pachońskiego, $Z$ dziejów książki polskiej w czasie drugiej wojny światowej (Warszawa 1970) Stanisława Pozyry czy o tomie studiów poświęconym książce w Lublinie w XIX i XX wieku ${ }^{69}$. W popularnej serii Ossolineum Książki o Książce ukazały się m.in. Sennewaldowie księgarze i wydawcy warszawscy Andrzeja Skrzypczaka (1969), Ambasador polskiej książki w Paryżu. Władysław Mickiewicz Andrzeja Kłossowskiego (1971), Gawędy o księgarzach Zbysława Arcta (1972), Józef Zawadzki - ksiegarz, drukarz, wydawca Radosława Cybulskiego (1972), Jakub Mortkowicz księgarz i wydawca Marianny Mlekickiej (1974) czy Na obczyźnie. Ludzie polskiej książki Andrzeja Kłossowskiego (1984). W serii tej znalazły się także opracowania dotyczące współczesnej problematyki, o czym niżej. Ciekawym i szeroko zakrojonym projektem badawczym była praca Marii Kocójowej Krakowski świat książki doby autonomii galicyjskiej, rozpatrująca kwestie rozpowszechnienia w szerokim kontekście kultury książki ${ }^{70}$. Praca ukazała się drukiem w 1990 roku, a więc już u progu nowej epoki. Wiele biogramów wybitnych i znanych księgarzy znalazło się w Polskim słowniku biograficznym, którego wydawanie wznowiono po 1956 roku, a później w Słowniku pracowników książki polskiej ${ }^{71}$. Swoje miejsce ma także problematyka księgarska w Encyklopedii wiedzy o książce ${ }^{72}$ i Encyklopedii współczesnego bibliotekarstwa polskiego ${ }^{73}$. Przybyło wydawnictw źródłowych, głównie pamiętników księgarzy, m.in. Jana Michalskiego, Ludwika Fiszera, Jana Jachowskiego, Tadeusza Męczyń-

${ }^{69}$ Np. Studia $z$ dziejów drukarstwa i księgarstwa w Lublinie w XIX i XX wieku, red. B. Szyndler, Lublin 1988.

${ }^{70}$ M. Kocójowa, Krakowski świat książki doby autonomii galicyjskiej (kształtowanie nowego modelu w latach 1867-1882), Kraków 1990.

${ }^{71}$ Słownik pracowników książki polskiej, red. I. Treichel, Warszawa-Łódź 1972; Słownik pracowników książki polskiej. Suplement, red. I. Treichel, Warszawa-Łódź 1986.

${ }^{72}$ Encyklopedia wiedzy o książce, red. A. Birkenmajer, B. Kocowski, J. Trzynadlowski, Wrocław 1971.

${ }^{73}$ Encyklopedia współczesnego bibliotekarstwa polskiego, red. K. Głombiowski, B. Świderski, H. Więckowska, Wrocław 1976, / rec. J. Baumgart, „Roczniki Biblioteczne” 1977, z. 3-4, s. 976983. 
skiego, Stanisława Malawskiego, Stefana Szpingera, Stefana Dippla ${ }^{74}$. Poważnym dokonaniem tamtego czasu jest niewątpliwie Bibliografia katalogów księgarskich Jadwigi Rudnickiej ${ }^{75}$.

Tematyka księgarska żywo interesowała też środowiska bibliofilskie, które względnie swobodnie rozwijały swoją działalność po $1956 \mathrm{roku}^{76}$. Dostrzec to można w wydawnictwach bibliofilskich ${ }^{77}$, a także w publicystyce.

W sposób jednak najbardziej intensywny i wielowątkowy rozwinęły się badania nad księgarstwem w Instytucie Książki i Czytelnictwa przy Bibliotece Narodowej. Jedną z dwóch podstawowych grup podejmowanych tam tematów było „funkcjonowanie instytucji sprzyjających kształtowaniu i rozwojowi czytelnictwa (bibliotek, księgarń i innych form kolportażu książki) oraz upowszechniających wiedzę o książce w skali masowej (prasa, radio, kino, telewizja)" ${ }^{\prime 7}$. Z warsztatów badawczych IKiCz-u wyszło wiele prac, mniejszych i większych, z zakresu historii handlu książką, w tym m.in. dotyczące Królestwa Polskiego w drugiej połowie XIX wieku Radosława Cybulskiego, Janusza Kosteckiego i Mariana J. Lecha ${ }^{79}$. Jednakże największy ilościowo jest dorobek badawczy i wydawniczy tej instytucji w obszarze zagadnień współczesnego księgarstwa, oparty na szeroko zakrojonych badaniach terenowych. We wstępie do pierwszej obszerniejszej pracy na ten temat nakreślono w imieniu Zakładu Organizacji i Propagandy Czytelnictwa $\mathrm{IKiCz}$ cel podejmowanych inicjatyw. „Praca, którą oddajemy obecnie w ręce czytelników - czytamy - charakterem swym odbija znacznie od poprzednio publikowanych prac Instytutu Książki i Czytelnictwa. Podczas bowiem gdy tamte próbowały oświetlić zainteresowania różnych kręgów czytelniczych z punktu

74 J. Michalski, 55 lat wśród książek. Wspomnienia, wrażenia, rozważania, z przedm. W. Borowego, Wrocław 1950 (2. wyd. Wrocław 1976 w serii Ksiażzi o Książce); L. Fiszer, Wspomnienia starego księgarza, Warszawa 1959; J. Jahowski, Wspomnienia poznańskiego księgarza i wydawcy. Odczyt..., Poznań 1959; T. Męczyński, Lata z książka. Wspomnienia księgarza 1907-1957, Łódź 1962; S. Malawski, Ksieggarskie konspiracje, Warszawa 1966; S. Szpinger, Na szerokiej drodze (pamiętnik księgarza), Łódź 1974; S. Dippel, O księgarzach, którzy przeminęli, Wrocław 1976.

${ }^{75}$ J. Rudnicka, Bibliografia katalogów księgarskich wydanych w Polsce do końca XVIII wieku, Warszawa 1975.

${ }^{76}$ Zob.: C. i J. Duninowie, Philobiblon polski..., s. 56-86.

${ }_{77} \mathrm{Z}$ reguły były to, oprócz publikacji w periodykach, drobne druki poświęcona księgarzom i antykwariuszom, jak np. Stefan Kamiński ksieggarz i wydawca, Kraków 1972.

${ }^{78}$ N. Kraśko, Instytut Książki..., s. 215.

79 R. Cybulski, Formowanie się modelu kapitalistycznego przedsiębiorstwa wydawniczo-księgarskiego w Polsce w latach 1800-1831, „Studia o Książce” 1976, t. 6, s. 101-130; J. Kostecki, Handel i rozdawnictwo książek w Królestwie Polskim w II połowie XIX wieku, „Studia o Książce” 1979, t. 9, s. 65-101; M. J. Lech, Księgarze i księgarnie w Królestwie Polskim 1869-1905. Materiały ze źródeł archiwalnych, Warszawa 1980; tenże, Ludzie druku i ksiąski w Królestwie Polskim 18671907. Ksztattowanie się struktur społecznych, Warszawa 1983. 
widzenia wykorzystania zasobów bibliotecznych, percepcji określonych tytułów i poszczególnych działów piśmiennictwa, czy wreszcie wpływu lektur na kształtowanie się poziomu kulturalnego w określonych środowiskach, praca ta wchodzi na nie obserwowany dotychczas przez nas teren księgarstwa. Dla praktycznego realizowania polityki kulturalnej jest przecież sprawą nieobojętną, jak kształtuje się stosunek księgarni do potrzeb nabywcy książek. Nie idzie tutaj oczywiście o kwestie handlowe, te bowiem wchodzą w zakres zainteresowań innych instytucji. Przedmiotem zaś naszych obserwacji jest to, co stanowi specyfikę księgarstwa, a więc zaspokajanie potrzeb czytelniczych ludności”"80. W ciągu niespełna paru lat opracowano i wydano kilka istotnych analiz rynku księgarskiego - podaży, popytu, informacji i organizacji pracy. Niezwykle obiecującym i szeroko zakrojonym projektem były Księgarnie i ich klienci Bohdana Cywińskiego ${ }^{81}$. Dokonano w nim analizy rynku księgarskiego w województwie, lubelskim. Niestety, nie objęto badaniami pozostałych. Ponadto zmiana podziału administracyjnego kraju utrudniła powtórzenie zastosowanej wcześniej procedury. Cywińskiemu udało się jednak uchwycić i pokazać system dystrybucji wydawnictw w warunkach gospodarki uspołecznionej sieć księgarską, zadania i rolę poszczególnych placówek, wpływ ich lokalizacji, kręgi odbiorców, wreszcie dynamikę i strukturę sprzedaży. Równolegle, w 1966 roku ukazała się monografia Radosława Cybulskiego Popyt na rynku ksiegarskim na tle przemian społeczno-gospodarczych w Polsce Ludowej. Autor, mający już na swoim koncie kilka szczegółowych opracowań, dokonał analizy rynku księgarskiego w kontekście przeobrażeń demograficznych i ekonomicznych oraz społecznych i kulturalnych, a także polityki wydawniczej państwa, odnosząc się również do zjawisk zachodzących poza Polską ${ }^{82}$. Prace te korespondowały z badaniami nad czytelnictwem i miały charakter praktyczny, dlatego też tak duży nacisk kładziono na zagadnienia związane $\mathrm{z}$ właściwym rozpoznaniem potrzeb odbiorców i odpowiednią informacją, reklamą i rolą samego księgarza. Już pierwszy, wycinkowy rekonesans z 1960 roku miał na celu „zarejestrowanie tych wszystkich tytułów, które wpłynęły do księgarni i z jakichkolwiek względów w małych ilościach egzemplarzy, zostały sprzedane w ciągu dwóch tygodni i księgarnia zarejestrowała dalsze zainteresowanie tymi książkami, innymi słowy: o te przypadki, kiedy zaopatrzenie księgarni

\footnotetext{
${ }^{80}$ R. Cybulski przy współpracy M. Jagły, Nowości na rynku księgarskim, Warszawa 1961, s. [III].

${ }^{81}$ B. Cywiński, Księgarnie i ich klienci na podstawie badań $w$ województwie lubelskim, Warszawa 1966.

${ }^{82}$ R. Cybulski, Popyt na rynku ksiegarskim na tle przemian społeczno-gospodarczych $w$ Polsce Ludowej, Warszawa 1966.
} 
nie zaspokoiło lokalnego popytu na jakiś tytuł"83. Niepowtarzalną wartość dokumentacyjną ma studium Cybulskiego na temat sprzedaży Małej Encyklopedii Powszechnej PWN, pierwszego i długo wyczekiwanego tego rodzaju wydawnictwa w Polsce po drugiej wojnie światowej ${ }^{84}$. Z kolei praca Księgarz radzi czytelnikom, oparta na wynikach badań przeprowadzonych w 25 księgarniach na terenie całego kraju, miała przynieść odpowiedź na dwa pytania: „1. Jaka jest funkcja księgarza jako doradcy w doborze kupowanych przez czytelników książek? 2. Jaką rolę spełniają masowe środki informacji (radio i prasa) w kształtowaniu zainteresowań publiczności odwiedzającej księgarnie?" 85 .

Cybulski i Cywiński postrzegali księgarstwo jako ogniwo systemu upowszechniania książki, ich badania inspirowane były przede wszystkim socjologią literatury, krążyły w zasadzie wokół zagadnień czytelnictwa. Natomiast z ekonomicznego punktu widzenia rozpatrywał problematykę księgarską Zdzisław Krasiński - ekonomista, współpracujący z IkiCz-em ${ }^{86}$. W 1963 roku ogłosił obszerny artykuł pt. Elementy rynku książki ${ }^{87}$, a następnie przygotował i wydał w Stowarzyszeniu Księgarzy Polskich Studium struktury dnia roboczego i wydajności pracy pracowników księgarskich (Warszawa 1965), które przynosi szereg ciekawych ustaleń i obserwacji.

Swego rodzaju podsumowaniem wieloletnich badań nad rynkiem książki w IKiCz-u są syntezy Radosława Cybulskiego: Księgarstwo w społeczeństwie współczesnym ${ }^{88}$ - popularnonaukowy zarys problematyki, wydany dwukrotnie; Książka współczesna. Wydawcy - rynek - odbiorcy (Warszawa 1986) oraz słownik Wspótczesne polskie księgarstwo, przygotowany pod jego redakcją ${ }^{89}$. Ostatnie dwie publikacje weszły do obiegu w okresie nasilającego się kryzysu ekonomicznego, na kilka lat przed transformacją, która objęła także rynek książki. Rynek ten powrócił, nie bez perypetii, do form znanych sprzed 1950 roku $^{90}$.

${ }^{83}$ R. Cybulski przy współpracy M. Jagły, Nowości..., s. 5.

${ }^{84}$ R. Cybulski, Geografia sprzedaży Małej Encyklopedii Powszechnej PWN, Warszawa 1962.

${ }^{85}$ R. Cybulski, Księgarz radzi czytelnikom, Warszawa 1965.

${ }^{86}$ Nakładem IkiCz-u wydał pracę Miejsce książki fachowej i naukowej w życiu kulturalnym inteligencji (Na przykładzie miast powiatowych województw poznańskiego i zielonogórskiego), Warszawa 1965.

87 Z. Krasiński, Elementy rynku książki, „Ruch Prawniczy, Ekonomicznym i Socjologiczny” 1963, z. 4, s. 145-163.

${ }^{88}$ R. Cybulski, Księgarstwo w społeczeństwie wspótczesnym, Wrocław 1970, 2. wyd. 1978 (seria Książki o Książce).

${ }^{89}$ Współczesne księgarstwo polskie. Mały słownik encyklopedyczny, red. R. Cybulski, Wrocław 1981.

${ }^{90}$ Zob.: S. Siekierski, Książka we współczesnej kulturze polskiej, Pułtusk 2006; B. Klukowski, 
Przywoływany już tekst Krzysztofa Migonia z 1972 roku, oprócz omówienia stanu badań i zauważalnych tendencji, zawierał szereg postulatów, sformułowanych już po dość obfitym wysypie różnego rodzaju prac w latach sześćdziesiątych. Migoń zwracał uwagę na potrzebę szeroko zakrojonych badań dziejów księgarstwa polskiego, w tym także edycji źródeł ${ }^{91}$. „Trzeba - pisał - ujawnić rolę księgarza i różnych form pracy księgarskiej w zaspokajaniu potrzeb intelektualnych społeczeństwa" ${ }^{22}$. Rolę tę - czytamy $\mathrm{w}$ innym miejscu - należy rozpatrzyć także w odniesieniu do różnych rodzajów piśmiennictwa „według kryterium językowego, problemowego, formalnego" ${ }^{93}$. W jakim stopniu zrealizowano w ciągu następnego ćwierćwiecza nakreślone przez Krzysztofa Migonia cele badawcze? Na pewno w 1989 roku wciąż daleko było jeszcze do „obszernego dzieła zbiorowego Historia księgarstwa polskiego" ${ }^{\prime 2}$. Z kolei badania nad współczesnym księgarstwem prowadono w ciekawych kierunkach, aczkolwiek spowolnił je pogłębiający się kryzys i rosnące niedobory na rynku książki, których nie sposób było $\mathrm{w}$ tamtych warunkach skutecznie rozwiązać na poziomie dystrybucji.

Istotne znaczenie dla rozwoju badań nad księgarstwem ma socjologia literatury, która w Polsce rozwinęła się na dobre w latach siedemdziesiątych i osiemdziesiątych XX wieku; wpływ prac Stefana Żółkiewskiego, Janusza Lalewicza, Krzysztofa Dmitruka i innych badaczy dostrzec można jeszcze w najnowszych opracowaniach dotyczących rynku książki, księgarstwa ${ }^{95}$.

Problematyka księgarska ma swoje ugruntowane miejsce w polskiej nauce o książce. Trudno jednak oprzeć się wrażeniu, nawiązując do przywołanej na początku Anny Migoniowej, że nie jest to miejsce pozostające w cieniu zagadnień bibliotecznych, historii książki, czytelnictwa - zagadnień, z którymi przecież wielokrotnie sprawy handlu książką wiążą się i splatają. Z gruntu jednak, co trzeba podkreślić, odmienne są środowiska, tworzące te dziedziny. Inne też, mimo wielu wspólnych płaszczyzn, przyświecają im cele. Świadomość i aktywność naukowa i organizacyjna bibliotekarzy zawsze była i jest wciąż wysoka, co nie pozostało bez wpływu na rozwój dyscypliny ${ }^{96}$, księgarzy już niekoniecznie. Z kolei atrakcyjność

M. Tobera, W tym niezwyklym czasie. Początki transformacji polskiego rynku książki (1989-1995), Warszawa 2013.

${ }^{91}$ K. Migoń, Problematyka księgarska..., s. 5-6.

${ }_{92}$ Tamże, s. 4.

${ }_{93}$ Tamże, s. 6.

94 Tamże.

${ }_{95}$ Np. M. Rychlewski, Książka jako towar, książka jako znak. Studia z socjologii literatury, Gdańsk 2013.

96 Tamże, s. 2. 
badawczą interesującego nas obszaru księgoznawstwa obniża wyjątkowo szczupła i fragmentaryczna dokumentacja archiwalna, jaką dysponujemy, i jaka pozwoliłaby odtworzyć historię poszczególnych firm i całej branży (dotyczy to również katalogów, których skrupulatnie nie archiwizowano). Były to przecież w większości firmy prywatne, nieprzywiązujące większej wagi do dokumentowania swojej działalności. Poza tym, burze dziejowe, a także inne kataklizmy, często unicestwiały to, co jakimś cudem się zachowało. Można było jednak się spodziewać, że scentralizowana struktura państwowego księgarstwa Polski Ludowej pozostawiła bogatą dokumentację. Jak się okazuje, i to nie. Żywiołowa transformacja w latach dziewięćdziesiątych ubiegłego wieku przyczyniła się do zaprzepaszczenia i rozproszenia większości archiwaliów Domu Książki, stąd - podobnież jak to ma miejsce w odniesieniu do wcześniejszych okresów - nieocenionym źródłem pozostaje prasa branżowa, która wcześniej rozwijała się dzięki wyjątkowej aktywności środowiska, a później w ramach systemu państwowej gospodarki i scentralizowanego ruchu zawodowego.

Struktura księgarstwa polskiego w latach 1950-1989 pozwalała na głęboką analizę dokumentów bieżącej działalności przedsiębiorstwa, jak i poszczególnych księgarń, co w warunkach gospodarki kapitalistycznej, wolnorynkowej jest utrudnione, albo w ogóle niemożliwe (tajemnica handlowa). Polscy badacze znali osiągnięcia obce w zakresie badań rynku, szczególnie francuskie i niemieckie, inspirowali się nimi ${ }^{97}$, jednak działali w zupełnie innych warunkach. Starający się przybliżyć polskiemu czytelnikowi osiągnięcia nauki zachodniej nasi wydawcy, musieli się sporo nieraz natrudzić, aby wytłumaczyć, że „w Polsce Ludowej powstał nie znany w krajach kapitalistycznych system wydawnictw socjalistycznych (...), który pozwala łatwiej rozwiązać swoiste zagadnienia w zakresie poszczególnych rodzajów publikacji" ${ }^{\prime 8}$. Specyfika rynku książki w kraju socjalistycznym, totalitarnym była poważnym ograniczeniem metodologicznym, które nie pozwalało skorzystać w pełni z zachodnich inspiracji, co widać szczególnie na przykładzie Rewolucji książki Roberta Escarpita. Z przyczyn oczywistych trudno było badaczowi obserwować pewne procesy, definiować zjawiska, które po prostu tutaj nie zachodziły. Były one charakterystyczne dla wolnego rynku, gdzie - nawet przy znaczącym udziale mecenatu państwa w zakresie kultury - działały jego mechanizmy, istniała konkurencja. Polscy biblio-

${ }_{97}$ Były to głównie przedsięwzięcia Roberta Escarpita (B. Cywiński, Księgarnie..., s. 6), ale także niemieckie, m.in.: Das Bücherlesen. Fakten und Motive, Hamburg 1968; obszerne kompendium Handuch des Buchhandels. Band III: Sortimentsbuchhandel, red. F. Hinze, Hamburg 1971.

${ }^{98}$ L. Marszałek, Posłowie do: R. Escarpit, Rewolucji książki, Warszawa 1969, s. 196. 
lodzy, bibliotekoznawcy i ekonomiści z Radosławem Cybulskim na czele postrzegali współczesne księgarstwo pragmatycznie. Ich badania oprócz ewidentnego celu poznawczego miały usprawnić dystrybucję wydawnictw w PRL. Niestety, choć z pewnością przyniosły szereg korzyści i pomagały w szkoleniu kadr itp., to jednak wskazywanych mankamentów nie udało się usunąć. Wypływały one bowiem nie tyle $\mathrm{z}$ niedomagań organizacyjnych czy niedostatecznej bazy, które zawsze zdają się być niewystarczające, ale $\mathrm{z}$ systemu politycznego i gospodarczego. W systemie tym ruch wydawniczy, odpowiedzialny przecież za prawidłowe zaspokojenie potrzeb czytelniczych społeczeństwa, realizował politykę partii, którą determinowały w znaczącym stopniu cenzura i propaganda. Potrzeby rynku były dla decydentów drugorzędne. Nie tylko zresztą w tej dziedzinie był to rynek producenta ze wszystkimi tego konsekwencjami.

$\mathrm{Z}$ dzisiejszego punktu widzenia prace $\mathrm{z}$ minionego okresu stanowią istotną część literatury przedmiotu, choć w sporym wymiarze mocno zdezaktualizowaną. Są one również nieocenionym źródłem historycznym dla poznania epoki. Badano księgarstwo takie, jakie istniało; analizowano rynek taki, jaki funkcjonował; postulowano modyfikacje, racjonalizacje takie, na jakie pozwał skostniały system, choć często okazywało się, że i te nie są możliwe do zaprowadzenia. Literatura ta wymaga lektury czujnej, historycznego przygotowania, świadomości kontekstów i uwarunkowań, także instytucjonalnych i technologicznych. Wiele prac, z pozoru trącących myszką, odpychających nieraz ideologicznym sztafażem, jest niezwykle pomocna w badaniach nad współczesnym księgarstwem, już przez sam wzgląd na wypracowaną terminologię. 


\section{Abstract \\ Book-selling in book studies in Poland since 1989}

The theme of book-selling, while present in the oldest texts on a history of books, has been considerably neglected for a long time. One of the main reasons was the nature of the market dealing with the selling of old books: many companies were responsible for two different kinds of services - publishing as well as book-selling. A significant change came in the second half of the nineteenth century. There came out manuals and guidebooks devoted to book-selling issues. Additionally, scholars and historians began to turn their interest to this kind of book distribution. One of the most important historical and theoretical texts on this subject includes Jan Muszkowski’s Życie ksiażki (1936; "A Life of the book"). The time after WWII saw a dynamic development of book-selling networks, which also gave rise to bibliophilic studies. It is important to remember, however, that these changes took place in a very specific context of the communist regime. Nevertheless, the research conducted at that time is of great value and remains useful even today. The most important texts that deserve attention are those authored by Radosław Cybulski and Bohdan Cywiński, affiliated with Instytut Książki i Czytelnictwa Biblioteki Narodowej (The Books and Readership Institute of the National Library). 